УДК 338.48:330.341.1

\title{
НАПРЯМКИ ПІДВИЩЕННЯ ЯКОСТІ ТРАНСПОРТНОГО ТУРИЗМУ ПІДПРИЕМСТВАМИ ТУРИСТИЧНОЇ ГАЛУЗІ В РЕКРЕАЦЙНИХ РЕГІОНАХ УКРАЇНИ
}

\author{
Копитко В. I., о.е.н., професор, декан факультету, \\ Терещак Ю.В., к.т.н.,доцент (Львівська філія ДНУЗТ ім. академіка В. Лазаряна)
}

Розглядаються напрямки підвищення якості транспортного туризму підприємствами туристичної галузі в рекреаиійних регіонах України з використанням культурно-пізнавального потенціалу курортних територій. Пропонується використання унікальних конкурентних переваг туристичного потенціалу Закарпатської області: прикордонне розтамування $i$ можливість організації тісної інформаційної та транскордонної співпраиі з сусідніми країнами із врахуванням транспортної складової. Розробка єдиного інформаційного простору туристичними операторами в иьому регіоні дозволить полегшити доступ на украӥнський ринок іноземним туристам, підвищити стандарти обслуговування відповідно до прийнятих міжнародних норм та привабливість для вітчизняних туристів, використовуючи різноманітні види транспорту $і$ якість надання послуги туристичними операторами на иій територіі позитивно вплине на конкурентоспроможсність послуги як товару.

Ключові слова: транспортний туризм, інноваційний продукт туристичних підприємств, культурно-пізнавальний туризм, інформаційний простір, рекреаційні регіони, туристичний потенціал регіону, якість туристичних послуг.

\section{НАПРАВЛЕНИЯ ПОВЫШЕНИЯ КАЧЕСТВА ТРАНСПОРТНОГО ТУРИЗМА ПРЕДПРИЯТИЙ ТУРИСТИЧЕСКОЙ ОТРАСЛИ В РЕКРЕАЦИОННЫХ РЕГИОНАХ УКРАИНЫ}

\author{
Копитко В.И. д.э.н., профессор, декан факультета, \\ Терещак Ю.В. к.М.н., доцент \\ (Львовский филиал ДНУЖТ им. академика В. Лазаряна)
}

\begin{abstract}
Рассматриваются направления повышения качества транспортного туризма предприятиями туристической отрасли в рекреачионных регионах Украины с использованием культурно-познавательного потенщиала курортных территорий. Предлагается использование уникальных конкурентных преимуществ туристического потенциала Закарпатской области: приграничное положение $u$ возможность организации тесного информационного $u$ трансграничного сотрудничества с соседними странали с учетом транспортной составляющей. Разработка единого информационного пространства туристическими операторами в этом регионе позволит облегчить доступ на украинский рынок иностранным туристам, повысить стандарты обслуживания в соответствии с принятылми международными нормами и привлекательностью для отечественных туристов, используя различные виды транспорта и качество предоставления услуги туристическими операторами на этой территории положительно повлияет на конкурентоспособность услуги как товара.

Ключевые слова: транспортный туризм, инновационный продукт туристических предприятий, культурно-познавательный туризм, информационное пространство, рекреационные регионы, туристический потенциал региона, качество туристических услуг.
\end{abstract}

(C) Копитко B.I., Терещак Ю.В.
Вісник економіки транспорту і промисловості № 53, 2016 


\title{
TENDENCIES OF IMPROVEMENT THE QUALITY OF TRANSPORT TOURISM BY TOURISM ENTERPRISES IN RECREATION AREAS OF UKRAINE
}

\author{
Kopytko V.I., Doctor of Economics, Professor, Dean of the Lviv branch, \\ Tereshchak Y.V., Ph.D., assistant professor Lviv branch \\ (Dnipropetrovsk National University of Railway Transport named after Ac. V. Lazaryan)
}

Tendences of improvement the quality of transport tourism by enterprises in the tourism industry in recreational regions of Ukraine using cultural and educational potential of resort are reviewed.It is advisable for tourism industry businesses in resort areas to combine the two models concept of cultural and educational tourism, where the element of knowledge involving natural and cultural values serves as the main purpose of trip by transport, or as an additional service, which is typical for tourist resort areas. This will provide the methodological basis for improvement of regulating cultural tourism methods based on the mechanism of feedback with the consumer in the system of administrative and public forms of management. It is proposed to use the unique competitive advantages of tourism potential of Transcarpathian region : border location and the possibility of information and trans-boundary cooperation with neighbouring countries with regard to the transport component. Development of common information space by tourist operators in the region will facilitate access to the Ukrainian market for foreign tourists, increase service standards in accordance with accepted international standards and attraction for domestic tourists using various mode of transport.Tourism enterprises' innovative product in the recreational tourism sector can be called new service proposals, directions, routes that are offered and sold in the market, and the quality of services given by tour operators in the area affect the competitiveness of the service as goods.

Keywords: transport tourism, tourism enterprises' innovative product, cultural and educational tourism, information space, recreational areas, tourist potential of the region, the quality of tourist services.

Постановка проблеми та їі зв'язки 3 науковими чи практичними завданнями. Туристично-рекреаційні регіони потенційно становлять значну частку економічного потенціалу України, оскільки при ефективному використанні цього потенціалу можна отримувати грошові надходження, які сприятимуть збільшенню доходів регіональних бюджетів. Вирішення зазначених проблем, враховуючи особливості туристичнорекреаційних регіонів, пов'язане 3 вдосконаленням інфраструктури туризму, його кадрового забезпечення та сформованих форм управління. Одним із таких регіонів $\epsilon$ Закарпатська область. Незначне зростання економічних показників суб'єктів туристської індустрії не завжди означає задоволеність споживача послуг, адже Україна, займаючи одне 3 провідних місць в Європі за рівнем забезпеченості цінними природними та культурними ресурсами, залишається аутсайдером цих світових процесів. Тому використання культурно-пізнавального потенціалу курортних територій, підвищення якості транспортного туризму $\mathrm{i}$ створення сучасної концепції розвитку культурнопізнавального туризму потребують вивчення.

Аналіз останніх досліджень i публікацій. Внесок у розвиток теорії і методики туристичної галузі внесли такі вчені, як: В. Басюк O.B.[2],I. Богатюк [11], I. Безуглий, Д. Стеченко, [12], М.Бойко, С.Мельниченко, Т.Ткаченко[13], С. Куніцин [4], В.Руденко [1]. Питаннями впливу якості послуг на ефективність туристської діяльності займалися такі дослідники, як А. Астахов[10], М. Денисенко, Н. Терещенко [9], висвітлення теоретичних проблем і практичних аспектів транспорту, транспортної інфраструктури та їх використання в туристичній сфері стали предметом дослідження вчених: О.Бордун [14], Л. Медвідь [15], О. Пікулик [16] та ін.

Виділення невирішених частин загальної проблеми. Не дивлячись на велику кількість досліджень в контексті надання якісних туристичних послуг туристичними підприємствами, специфічні особливості регулювання якості транспортного обслуговування та відповідно його вплив на 
культурно-пізнавальний туризм у курортних територіях вивчені недостатньо.

Формування цілей статті (постановка завдання Подальші дослідження вимагають визначення напрямків підвищення якості послуг транспортного туризму підприємствами туристичної галузі у рекреаційних регіонах України, що дозволить підвищити соціальну та екологічну ефективність цієї діяльності на курортних територіях.

\section{Виклад основного матеріалу} дослідження. Враховуючи особливості культурно-пізнавального туризму та його місце в цілому в індустрії подорожей, можна розглядати цей процес як сукупність соціальноекономічних відносин, що виникають в процесі вдосконалення способів управління якістю послуг культурно-пізнавального туризму курортних територій. Важливим тут $є$ той факт, що даний вид туристських послуг може мати як самостійну привабливість, так i виступати супутніми, залежними послугами, обсяг яких буде залежати в курортних територіях від кількості осіб, яким надаються лікувальнооздоровчі послуги.

Розвиток рекреації та туризму як стратегічний напрям довгострокової регіональної політики держави, зафіксовано у переліку пріоритетних напрямів розвитку 17 регіонів України. Спільним для них $\epsilon$ стимулювання розвитку підприємництва в туристичній сфері, сприяння розбудові та модернізації туристичної та рекреаційної інфраструктури із широким використанням рекреаційних та лікувально-оздоровчих ресурсів[2].
Враховуючи те, що кількість міжнародних туристів у 2015 році зросла на 50 млн. чоловік і досягла рекордних 1млрд.184млн.осіб[8], сучасний стан розвитку економіки України та іiі регіонів, не характеризується зростаючим попитом на внутрішньому ринку туристичних послуг і не відкриває можливості для багатьох вітчизняних економічних суб'єктів і не дає можливість також визначити точки довгострокового стійкого зростання туристично-рекреаційного комплексу i виробити механізми, що підвищують доступність і конкурентоспроможність послуг галузі, тому справедливо відзначає автор [11,c.49-50], що розвиток туристичнорекреаційних комплексів в Україні характеризується певною невідповідністю між платоспроможним попитом на туристичнорекреаційні послуги та пропозицією, яка визначається рекреаційною місткістю діючих оздоровниць.

В інфраструктурі рекреаційної галузі Західного регіону України важливе місце займають колективні засоби розміщення. Вони поділяються на спеціалізовані засоби розміщення, готелі та аналогічні засоби розміщення (рис.1). За наявністю рекреаційних ресурсів Львівська область займає одне 3 провідній місць в державі і у спеціалізованих засобах було розміщено 170,8 тис. осіб і серед областей Карпатського регіону за сумарним потенціалом природних рекреаційних ресурсів вона поступається лише Закарпаттю [1, с. 124], де виявлено i досліджено 360 джерел мінеральних вод[3].

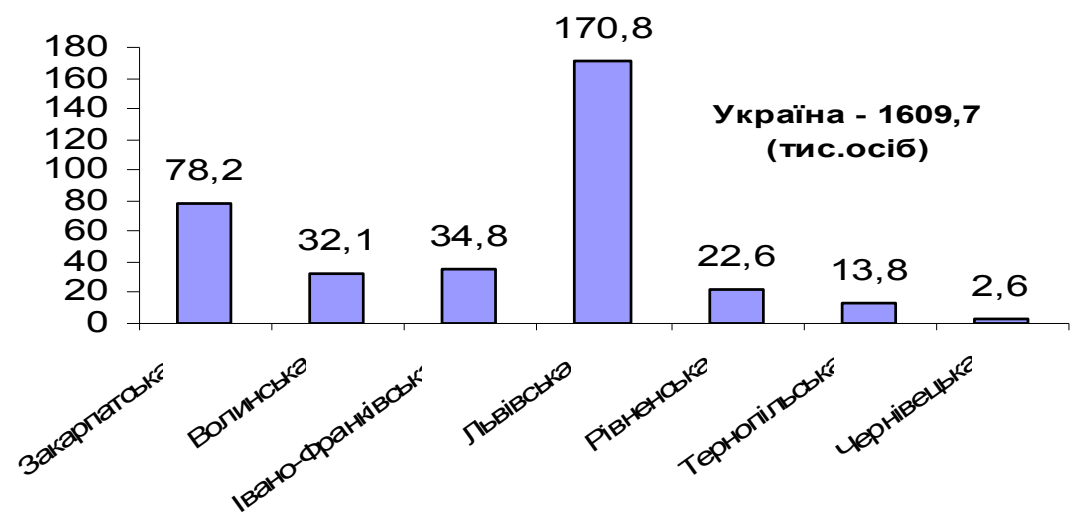

Рис. 1. Кількість розміщуених осіб у спещіалізованих засобах розміщення по Украӥні та Західному регіону у 2014 роиі

Вісник економіки транспорту і промисловості № 53, 2016 
Якщо проаналізувати динаміку туристичних потоків у Закарпатті(табл.1) кількість туристів, що обслуговуються суб'єктами туристичної діяльності становить 11625 осіб і це становить лише 4,8\% всіх туристів України, що значно менше кількості туристів, які обслуговуються суб'єктами туристичної діяльності Львівської та ІваноФранківської областей.

Табличяя 1[5, с. 14]

Кількість туристів, щуо обслуговуються суб'єктами туристичної діяльності, по Украӥні та Західному регіону у 2014 роиі

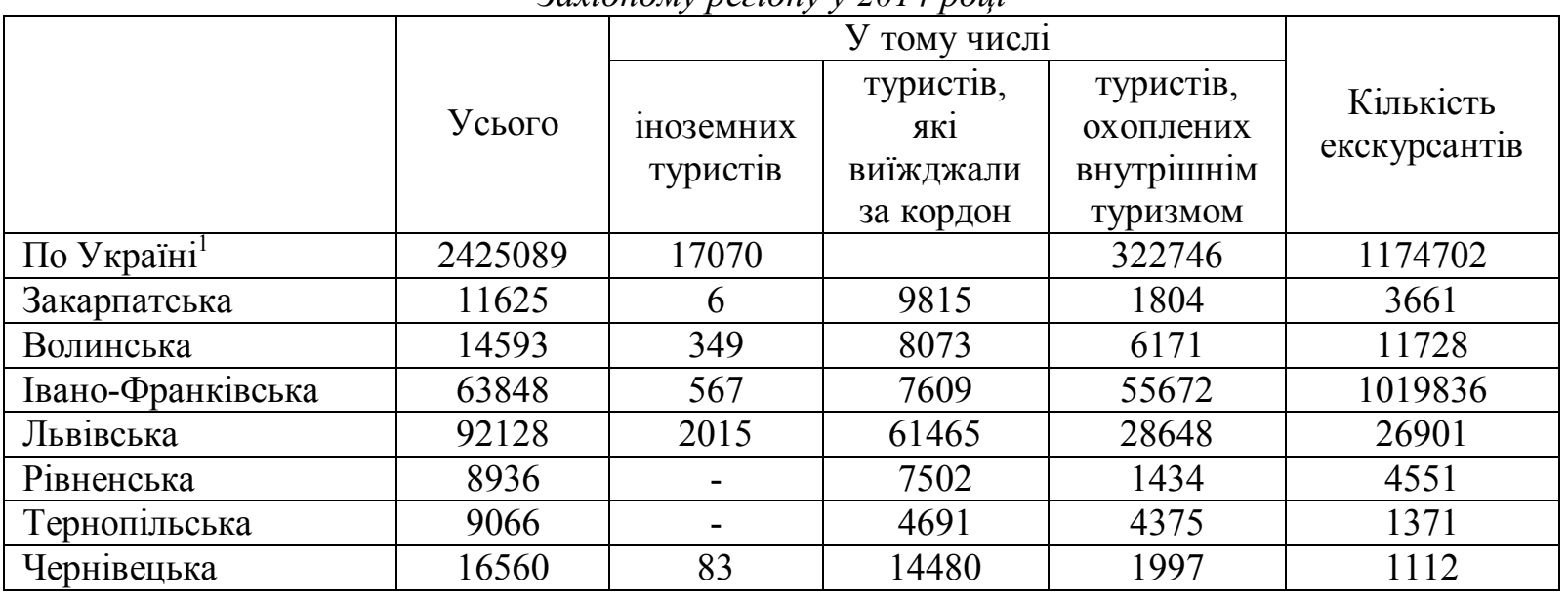

Із 2198 субєктів туристичної діяльності по Україні (табл.2) у Закарпатській області лише 40 і доходів від надання туристичних послуг отримано отримано 7017,4 тис.грн., що становить $1,3 \%$ від загальноукраїнського показника. Однак, у регіональній індустрії туризму у Закарпатті рівень сервісу та кваліфікації персоналу не завжди відповідає запитам і очікуванням клієнтів, має місце незадовільне співвідношення таких показників як «ціна-якість».

Табличя 2[5,c.15]

Субєкти туристичної діяльності по Украӥні та Західному регіону у 2014 роцуі

\begin{tabular}{|c|c|c|c|c|c|c|c|c|c|}
\hline & \multicolumn{5}{|c|}{ Юридичні особи } & \multicolumn{4}{|c|}{ Фізичні особи-підприємці } \\
\hline & \multirow[b]{2}{*}{$\begin{array}{l}5 \\
0 \\
0 \\
0 \\
0 \\
0 \\
0 \\
\lambda\end{array}$} & \multicolumn{3}{|c|}{ у тому числі } & \multirow[b]{2}{*}{ 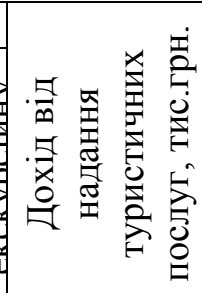 } & \multirow[b]{2}{*}{$\begin{array}{l}F \\
0 \\
0 \\
0 \\
0 \\
0 \\
0 \\
\lambda\end{array}$} & \multicolumn{2}{|c|}{ у тому числі } & \multirow[b]{2}{*}{ 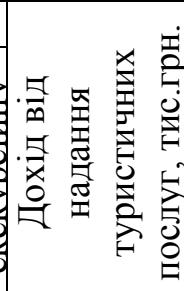 } \\
\hline & & 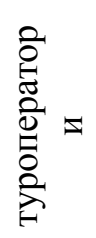 & 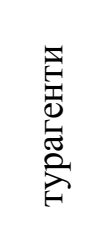 & 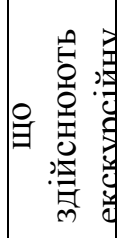 & & & 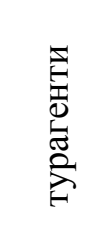 & 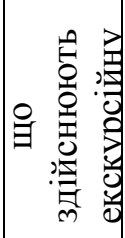 & \\
\hline По Україні & 2198 & 667 & 1473 & 58 & 5432673,4 & 1687 & 1596 & 91 & 133971,1 \\
\hline Закарпатська & 40 & 16 & 22 & 2 & 7017,4 & 34 & 34 & - & 2457,0 \\
\hline Волинська & 27 & 15 & 10 & 2 & 5030,5 & 53 & 50 & 3 & 4536,6 \\
\hline $\begin{array}{l}\text { Івано- } \\
\text { Франківська }\end{array}$ & 48 & 22 & 23 & 3 & 205352,1 & 51 & 48 & 3 & 1573,6 \\
\hline Львівська & 143 & 52 & 79 & 12 & 166910,8 & 92 & 69 & 23 & 7842,7 \\
\hline Рівненська & 30 & 6 & 23 & 1 & 4165,5 & 39 & 38 & 1 & 2820,7 \\
\hline Тернопільська & 22 & 1 & 9 & 3 & 2912,9 & 27 & 26 & 1 & 1369,4 \\
\hline Чернівецька & 44 & & 20 & - & 6432,3 & 24 & 24 & - & 2225,3 \\
\hline
\end{tabular}

Йдеться про пошук туристичними підприємствами нових форм управління розвитком транспортного та культурнопізнавального туризму, що вимагає оцінки соціально економічної ефективності 
формування та управління такими туристично-рекреаційними регіонами, особливо в аспекті їх територіального, інфраструктурного, економічного i соціального розвитку і дозволить поєднати 3 лікуванням та відпочинком за допомогою транспортних засобів культурнопізнавального туризму.

Згідно 3 шкалою оцінки клімату рекреаційних районів територія Закарпатської області отримала оцінку "найкраща" за сумарною тривалістю сприятливих для відпочинку періодів, що дає можливість стверджувати про перспективи розвитку транспортної інфраструктури Західного регіону та залізничного туризму на Закарпатті. Закарпаття межує із рекреаційними територіями Львівської та Івано-Франківської областей, де можливо залучення осіб у лікувально-оздоровчих закладах до транспортного і відповідно культурнопізнавального туризму на Закарпатті.

Сприятливе географічне становище та існуючий потенціал туристичної галузі Закарпаття в сфері культури несе в собі значні можливості в умовах євроінтеграційних процесів в Україні. У зв'язку 3 цим важко переоцінити ту роль i ті можливості, які відкриває туристично-рекреаційний комплекс Закарпатської області у розвитку професійних ресурсів i людського капіталу регіону, становлення культурно-освітнього рекреаційного центру на території області. Реалізація зазначених перспектив потребує участі державних інститутів у вирішенні низки практичних проблем, які гальмують ефективну взаємодію сфер туризму, культури та освіти.

На сьогоднішній день на Закарпатті туристична діяльність не завжди $є$ рекреаційною, а рекреаційна - туристичною. Воно і не може бути в повній мірі реалізоване, однак об'єднати може це в певній мірі транспорт. Тому $є$ необхідність об'єднання зусилль туристичних операторів (агентів) щодо забезпечення створення та реалізації туристичного продукту, який характеризується як попередньо розроблений комплекс туристичних послуг, який поєднує не менше ніж дві такі послуги[6, с.230]. Туристична галузь Закарпатської області не може існувати без розвинутої транспортної інфраструктури туризму [15], яка на думку О.
Пікулика[16, с.287], є сукупністю транспортних комунікацій, об'єктів 3 обслуговування пасажирських перевезень, об'єктів технічного обслуговування та ремонту.

Довжина автомобільних доріг у Закарпатті загального користування протягом 2014p. не змінилась і становила 3347,8 км, у т.ч. 3 твердим покриттям - 3337,9 км. Загальна регіональна залізнична мережа зв'язує область 3 Угорщиною, Румунією та Словаччиною i, відповідно, з західноєвропейськими країнами. Область також має три виходи на загальнодержавні залізничні мережі через Карпатські перевали. Експлуатаційна довжина залізничних колій становить 598 км, 3 яких 43,5\% з електровозною тягою [17, с.9-10].

Залучити всіх бажаючих до транспортного і відповідно культурнопізнавального туризму на Закарпатті можна, викокористовуючи вузькоколійний маршрут «Боржавська вузькоколійка», що пролягає Берегівським, Виноградівським та Іршавським районами. Карпатська залізниця i досі об'єднує міста Карпатського регіону в Україні (Закарпатська область), Румунії (лісова залізниця Вісеул-де-Сус), Словаччині (дитяча залізниця у м. Кошіце), Польщі (Бещадська Лісова Колейка, м.Цісно), Угорщині (вузькоколійні залізниці в містах Палхаза, Мішкольц, Ніредьхаза)[7,с.103].

Створення ПАТ "Українська залізниця" сприятиме підвищенню якості транспортного туризму, що дозволить в регіонах Україні зробити сприятливий вплив на туризм в цілому, оптимізувати структуру туристських пакетів i забезпечити задоволення споживчого попиту, сприяти розвитку нових форм туризму, забезпечити транспортну доступність нових туристських напрямків і сприяти економічному розвитку цих регіонів i як у більшості економічно розвинених країн світу[4, с.40], призводить до підвищення масової мобільності та свободи переміщення широких верств населення 3 метою змістовного проведення дозвілля.

Для цього необхідно забезпечити розробку управлінських рішень щодо визначення показників, які обумовлюють надання якісного туристичного продукту, що розглядається як важлива складова програми управління якістю туристичних послуг [10, 62]. Ефективна діяльність підприємств туристичної індустрії можлива за таких умов[9,с.135]: 
- комплексна туристична послуга задовольняє всі вимоги вітчизняного законодавства та інші вимоги регіону, суспільства;

- туристична послуга відповідає потребам сфери застосування або призначення; - туристичний продукт задовольняє вимоги та очікування споживачів; - туристичний продукт відповідає стандартам та технічним вимогам; - комплексна туристична послуга, з одного боку, спрямована на одержання прибутку суб'єктами туристичної індустрії, з другого - пропонується споживачам та туристичним агентам за конкурентоспроможними цінами;

- туристичний продукт задовольняє всі вимоги безпеки.

Туристично-рекреаційні зони $\epsilon$ значною частиною економіки Карпатського регіону і особливо Закарпаття, оскільки мають величезний потенціал формування доходів регіонального бюджету. У зв'язку 3 цим актуальною стає проблема розробки моделей i методик для оцінки соціально-економічної ефективності формування та управління такими туристично-рекреаційними зонами, особливо в аспекті їх територіального, інфраструктурного, економічного і соціального розвитку. Моделі для вимірювання та оцінки ефективності також є важливими для розробки механізму формування i управління цими територіями. Істотним залишається матеріально-технічна та інфраструктурна відсталість рекреації. Територіальна структура Закарпаття відрізняється нерівномірним характером освоєння території рекреаційні райони відчувають перевантаження, в той же час ресурсний потенціал перспективних гірських, передгірських використовується не в повному обсязі.

Тут необхідні інновації, які в рекреаційно-туристичній сфері можна розглядати як результат дій, які спрямовані на створення нового продукту, освоєння нових ринків, впровадження інформаційних технологій, вдосконалення процесу надання рекреаційно-туристичних послуг, створення стратегічних альянсів для здійснення бізнесу, впровадження сучасних організаційноуправлінських форм діяльності спеціалізованих підприємств. [13, с. 64]. Якість послуги на цій території як чинника, що надаватимуть туристичні підприємства, впливає на конкурентоспроможність послуги як товару i визначального задоволення споживача від придбання послуги як споживчої цінності, що відбивається в соціальній ефективності туризму.

Для регіонального рекреаційнотуристичного бізнесу переваги можна вбачати в наступному: зниження трансакційних витрат, поліпшення можливостей для більш результативного виходу на ринки, активізація інноваційної діяльності, удосконалення і модернізація ринкової інфраструктури надання рекреаційно-туристичних послуг[12,с.14], а функціональногосподарську систему індустрії туризму розглядати як три складові: гостинності, транспорту та туристично-оздоровчої діяльності [14, с.148].

Тому на курортних територіях підприємствам туристичної галузі доцільно об'єднати концепцію двох моделей організації культурно пізнавального туризму, де елемент пізнання i прилучення до природних і культурним цінностям виступає або як головна мета подорожі транспортом, або як додаткова послуга, що властиво туристичним продуктам курортних територій $\mathrm{i}$ забезпечити методичну основу вдосконалення способів регулювання культурнопізнавального туризму на базі використання механізму зворотного зв'язку зі споживачем в системі адміністративних і громадських форм управління.

Одним із унікальних конкурентних переваг туристичного потенціалу Закарпатської області є прикордонне розташування і можливість організації тісної інформаційної та транскордонної співпраці 3 сусідніми країнами із врахуванням ролі транспортної складової. Розробка єдиного інформаційного простору туристичними операторами в цьому регіоні дозволить полегшити доступ на український ринок іноземним туристам, підвищити стандарти обслуговування відповідно до прийнятих міжнародних норм, підвищити привабливість для вітчизняних туристів, використовуючи різноманітні види транспорту.

Висновки даного дослідження i перспективи подальших робіт у цьому напрямку. Розвиток послуг та підвишення якості транспортного туризму дозволить в регіонах Україні зробити сприятливий вплив на туризм в цілому, туристичним 
підприємствам оптимізувати структуру туристських пакетів i забезпечити задоволення споживчого попиту, сприяти розвитку нових форм туризму, забезпечити транспортну доступність нових туристських напрямків і сприяти економічному розвитку іiі регіонів. Курортна територія Закарпаття володіє різноманітним туристичнорекреаційним потенціалом, який забезпечує створення як рекреаційних, так і культурнопізнавальних туристських продуктів. Розвиток туристичної діяльності на цій території $\epsilon$ перспективним у культурно-пізнавальній туристичній діяльності, включатиме рекреаційні послуги, а оздоровчі поїздки можуть також супроводжуватися наданням послуг культурної та пізнавальної спрямованості. Інноваційним продуктом туристичних підприємств у рекреаційнотуристичній сфері можуть називатися нові пропозиції послуг, напрями, маршрути, які пропонуються та реалізуються на ринку.

Якість надання послуги туристичними операторами на цій території впливає на конкурентоспроможність послуги як товару, що пов'язано 3 економічною ефективністю туристичної діяльності й визначальним задоволенням споживача від придбання послуги як споживчої цінності, що відбивається в соціальній ефективності туризму. Iз врахуванням конкурентних переваг туристичного потенціалу Закарпатської області прикордонного розташування можливість організації тісної інформаційної та транскордонної співпраці з сусідніми країнами забезпечить конкурентні переваги на ринку туристичних послуг, а культурно-пізнавальна послуга iз врахуванням транспортної складової може стати головною частиною туру на території 3 високим культурноісторичним потенціалом та унікальними природними об'єктами.

\section{СПИСОК ЛІТЕРАТУРИ}

1. Руденко В.П. Географія природноресурсного потенціалу України. У 3 -х частинах: Підручник. - К.: ВД "К. М.Академія" - Чернівці: Зелена Буковина, 1999. - 568 с.

2. Семенов В.Ф., Басюк О.В. Територіальні умови і стратегіï розвитку туризмув регіонах. Режим доступу: http://dspace.oneu.edu.ua/jspui/bitstream/pdf

3. Рекреаційний потенціал Закарпатської області//. Режим доступу: http:/zolota-pidkova. org.ua/rekreacijnyjpotencial-zakarpatsjkoi-oblasti.html

4. Куніцин С.В. Система показників оцінки конкурентоспроможності туристичного продукту//Ученые записки Таврического национального университета им. В.И. Вернадского. Серия «Экономика и управление». Том 24 (63). 2011 г. № 3. С. 4049.

5. Закарпаття - санаторії та туризм (Статистичний збірник)// Державна служба статистики України. Головне управління статистики у Закарпатській області, Ужгород $-2015,107 \mathrm{c}$.

6. Статистичний збірник "Регіони України"// Державна служба статистики України(ч.1) К.:2015, 306с.

7. Копитко В.І. Діяльність підприємств туристичної галузі, враховуючи регіональні особливості розвитку транспортного туризму //Збірник наукових праць Дніпропетровського національного університету залізничного транспорту імені академіка В. Лазаряна „Проблеми економіки транспорту”. - Д.: Видво Дніпропетр. нац. ун-ту залізн. трансп. ім. акад. В. Лазаряна, 2015. - Вип. 10. - с. 99-104.

8. Кількість міжнародних туристів зросла до рекордних 1,2 млрд людей// Режим доступу: http:/dt.ua/WORLD/kilkistmizhnarodnih-turistiv-zrosla-do-rekordnih-1-2mlrd-lyudey-197046_.html

9.Денисенко М.П., Терещенко Н.M. Формування системи управління якістю послуг у сфері туризму// Наукові праці МАУП. - 2014. - Вип.1(40). - С.134-138

10. Астахов А. Система управління якістю - інструмент удосконалення загальної системи управління організацією (підприємством) / А. Астахов, Л. Хриплива // Стандартизація, сертифікація, якість. - 2011. №4. - С.60-64.

11. Богатюк І.Г. Рекреаційні зони в Україні: стан та перспективи розвитку// Вісник Академії праці i соціальних відносин Федерації професійних спілок України. Серія: Право та державне управління. - 2011. - №4. - С.48-51.

12. Стеченко Д. М. Інноваційна політика кластероутворення в рекреаційно-туристичній

Вісник економіки транспорту і промисловості № 53, 2016 
сфері України / Д. М. Стеченко, I. В. Безуглий // Науковий вісник Чернігівського державного інституту економіки і управління. Серія 1 : Економіка. - 2014. - Вип. 2. - С. 9-18.

13. Стратегічний розвиток туристичного бізнесу:монографія /[Ткаченко T.I., Мельниченко С. В. , Бойко М. Г. та ін.]; за заг. ред. А. А. Мазаракі. - К.: Київ. нац. торг.екон. ун-т, 2010. - 596 с.

14. Бордун О. Стан та перспективи транспортного забезпечення туристичної індустрії Львівської області// Наукові записки. №2. 2011. ( Рекреаційна географія і туризм), c. $147-152$.

15. Медвідь Л. І. Транспортна інфраструктура як важливий чинник розвитку туристичної галузі регіону// Режим доступу:http://geopolitika.crimea.edu/arhiv/

2014/ tom10-v-2/029 medv.pdf.

16. Пікулик О. Б. Пріоритетні напрями розвитку транспортної системи Західного регіону України в умовах європейської інтеграції / О.Б. Пікулик . // Науковий . вісник Волинського національного університету ім. Лесі Українки. - 2008. - № 7. - С. 284-291. (Серія : Економічні науки).

17.Транспорт i зв'язок Закарпаття (Статистичний збірник)//Державна служба статистики України. Головне управління статистики у Закарпатській області, Ужгород $-2015,88 \mathrm{c}$.

Експерт редакційної колегії к.е.н., дочент УкрДУЗТ Полякова О.М.

УДК 005.934:33

\title{
УДОСКОНАЛЕННЯ ПРИНЦИПІВ ФОРМУВАННЯ ТА ФУНКЦІОНУВАННЯ НАГЛЯДОВИХ РАД В СИСТЕМІ ЕКОНОМІЧНОЇ БЕЗПЕКИ ПІДПРИЕМСТВА
}

\author{
Котов А. М., к.е.н., доцент, \\ Мозгова Л. О., к.е.н, \\ Іваніснко В.В. к.е.н., професор (ХНЕУ)
}

Розглянуто принципи формування наглядової ради та необхідність трансформачії ключових ї̈ компетенцій у зв'язку з рухом корпорачії по стадіях життевого ииклу. Виявлено необхідність поступового переходу від простої структури наглядової ради до більш складної через врегулювання виникаючих конфліктів в управлінні. Розвиваючи механізми формування $i$ функиіонування наглядової ради запропоновано використовувати ряд принцииів внутрішньої взаємодії членів ради.

Ключові слова: акціонерні товариства, корпоративне управління, економічна безпека, наглядова рада, структура, формування, життєвий цикл, загрози, принципи.

\section{СОВЕРШЕНСТВОВАНИЕ ПРИНЦИПОВ ФОРМИРОВАНИЯ И ФУНКЦИОНИРОВАНИЯ НАБЛЮДАТЕЛЬНЫХ СОВЕТОВ В СИСТЕМЕ ЭКОНОМИЧЕСКОЙ БЕЗОПАСНОСТИ ПРЕДПРИЯТИЯ}

\author{
Котов А. Н., к.э.н, доцент, \\ Мозговая Л. А., к.э.н., \\ Иваниенко В. В., к.э.н., профессор (ХНЭУ)
}

Рассмотрены принщииы формирования наблюдательного совета и необходимость трансформации ключевых ее компетенщий в связи с движением корпорачии по стадиям жизненного иикла. Выявлена необходимость постепенного перехода от простой структуры 